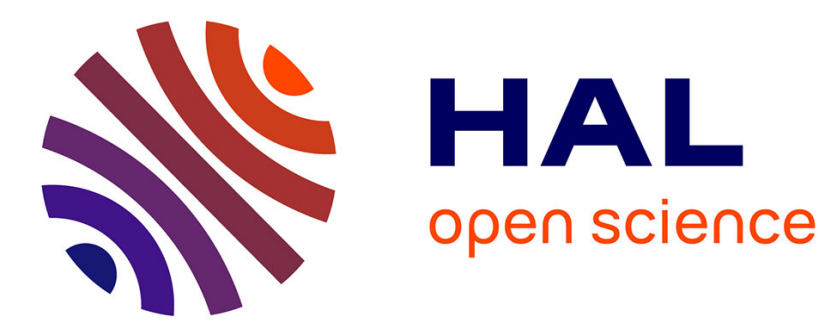

\title{
Giant linewidth enhancement factor and purely frequency modulated emission from quantum dot laser
}

B. Dagens, A. Markus, J.X. X Chen, J.-G. Provost, D. Make, O. Le

Gouezigou, J. Landreau, A. Fiore, B. Thedrez

\section{- To cite this version:}

B. Dagens, A. Markus, J.X. X Chen, J.-G. Provost, D. Make, et al.. Giant linewidth enhancement factor and purely frequency modulated emission from quantum dot laser. Electronics Letters, 2005, 41 (6), pp.323-324. 10.1049/el:20057956 . hal-03331161

\section{HAL Id: hal-03331161 \\ https://hal.science/hal-03331161}

Submitted on 1 Sep 2021

HAL is a multi-disciplinary open access archive for the deposit and dissemination of scientific research documents, whether they are published or not. The documents may come from teaching and research institutions in France or abroad, or from public or private research centers.
L'archive ouverte pluridisciplinaire HAL, est destinée au dépôt et à la diffusion de documents scientifiques de niveau recherche, publiés ou non, émanant des établissements d'enseignement et de recherche français ou étrangers, des laboratoires publics ou privés. 


\section{TU/e EmonONEN

\section{Giant linewidth enhancement factor and purely frequency modulated emission from quantum dot laser}

Citation for published version (APA):

Dagens, B., Markus, A., Chen, J. X., Provost, J. G., Make, D., Gouezigou, le, O., ... Thedrez, B. (2005). Giant linewidth enhancement factor and purely frequency modulated emission from quantum dot laser. Electronics Letters, 41(6), 323-324. DOI: 10.1049/el:20057956

DOI:

10.1049/el:20057956

Document status and date:

Published: 01/01/2005

\section{Document Version:}

Publisher's PDF, also known as Version of Record (includes final page, issue and volume numbers)

\section{Please check the document version of this publication:}

- A submitted manuscript is the version of the article upon submission and before peer-review. There can be important differences between the submitted version and the official published version of record. People interested in the research are advised to contact the author for the final version of the publication, or visit the $\mathrm{DOI}$ to the publisher's website.

- The final author version and the galley proof are versions of the publication after peer review.

- The final published version features the final layout of the paper including the volume, issue and page numbers.

Link to publication

\section{General rights}

Copyright and moral rights for the publications made accessible in the public portal are retained by the authors and/or other copyright owners and it is a condition of accessing publications that users recognise and abide by the legal requirements associated with these rights.

- Users may download and print one copy of any publication from the public portal for the purpose of private study or research.

- You may not further distribute the material or use it for any profit-making activity or commercial gain

- You may freely distribute the URL identifying the publication in the public portal.

If the publication is distributed under the terms of Article 25fa of the Dutch Copyright Act, indicated by the "Taverne" license above, please follow below link for the End User Agreement:

www.tue.nl/taverne

Take down policy

If you believe that this document breaches copyright please contact us at:

openaccess@tue.nl

providing details and we will investigate your claim. 


\section{Giant linewidth enhancement factor and purely frequency modulated emission from quantum dot laser}

B. Dagens, A. Markus, J.X. Chen, J.-G. Provost, D. Make, O. Le Gouezigou, J. Landreau, A. Fiore and B. Thedrez

Giant effective linewidth enhancement factors, close to 60 , are measured on a quantum dot laser under specific biasing conditions Consequently, $2.5 \mathrm{Gbit} / \mathrm{s}$ purely frequency modulated signal is obtained by direct current modulation at this operation point.

Introduction: Quantum dot (QD) lasers have received considerable interest in recent years owing to continuously improving QD materials and to expected high device performances. Low linewidth enhancement factor (LEF), down to 0.5 [1], high $\mathrm{T}_{0}$ and promising dynamic properties have recently been demonstrated [2]. These results should improve the usual quantum well (QW) laser performances, and finally allow the realisation, for example, of chirp-free directly-modulated lasers.

However, more disruptive properties can also be explored with quantum dot lasers. In particular, it has been observed that above the ground state (GS) lasing threshold, the gain of the excited state (ES) is not clamped. Owing to the limited number of available GS levels, carriers injected in the ES cannot fully relax to the GS and contribute to increase the ES gain (carrier pile-up). This phenomenon is unique in the semiconductor laser domain, and leads to new device properties. Simultaneous lasing of two allowed transitions, respectively the ground state level transition and the excited state level transition has, for example, already been reported [3].

In this Letter we have focused our investigation on a specific regime that appears at currents just below the ES threshold. In particular, we demonstrate that the GS filling implies giant linewidth enhancement factors (LEF) up to 60, far above any reported value for semiconductor lasers. As a result, purely frequency shift keyed (FSK) signal could be achieved by direct modulation of a semiconductor laser.

After a brief description of the investigated device, we will present effective linewidth enhancement factor measurements, followed by dynamic measurements near the ES threshold.

Device description: The laser used in our experiments was grown by molecular beam epitaxy [4]. The active region is formed by three layers of self-assembled InAs QDs, which are covered by a $5 \mathrm{~nm}$ InGaAs QW and separated from each other by a $40 \mathrm{~nm}$ GaAs spacer layer. The areal dot density of the lens-shaped QDs is $3 \times 10^{10} \mathrm{~cm}^{-2}$. The laser cavity is clad by $1.5 \mu \mathrm{m} \mathrm{Al} l_{0.7} \mathrm{Ga}_{0.3}$ As layers. Our device is a $1950 \mu \mathrm{m}$-long Fabry-Perot ridge-waveguide laser with $3 \mu \mathrm{m}$-wide stripe. Coated front and rear facet reflectivities equal, respectively, 79 and $93 \%$ at $1.3 \mu \mathrm{m}$. At $25^{\circ} \mathrm{C}$, the GS and ES transitions lase, respectively, at $13(1290 \mathrm{~nm})$ and $220 \mathrm{~mA}(1210 \mathrm{~nm})$ (Fig. 1). Both quantum dot size distribution and the Fabry-Perot cavity lead to a widely multimode emission.

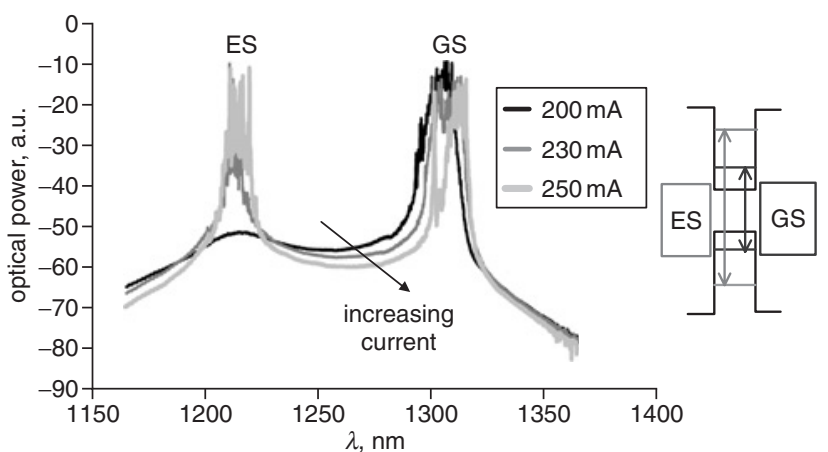

Fig. 1 QD laser spectra near ES threshold (220 mA) obtained under CW conditions

Linewidth enhancement factor measurements: The LEF has been measured on single GS and ES lasing modes with an interferometric method: the output optical signal from the laser operated under small-signal direct modulation is filtered in a $0.2 \mathrm{~nm}$ resolution monochromator and sent in a tunable Mach-Zehnder interferometer. From separate measurements on opposite slopes of the interferometer transfer function, phase and amplitude deviations are extracted against the modulating frequency, in the $50 \mathrm{MHz}$ to $20 \mathrm{GHz}$ range [5]. The LEF is given by the phase to amplitude responses ratio at the highest frequencies, in the limits of the device modulation bandwidth. In the present case, the device modulation bandwidth equals $3 \mathrm{GHz}$. The sign of the LEF is provided by the phase value. With this method, modulation-induced temperature effects are negligible [6]. LEF values between 2 and 5 are routinely measured on QW lasers with this method. Fig. 2 represents the ratio of phase and amplitude responses of a GS lasing mode at currents between 80 to $200 \mathrm{~mA}$. Corresponding extracted LEF values are reported in Fig. 3. Opposite to what is commonly observed with QW lasers, an increase of the LEF above GS threshold can be noticed. This effect is related to the index change induced by the carrier pile-up in the ES level. Just below the ES threshold a giant value of the ground state LEF, equal to 57 , is measured. It is attributed to the complete filling of the available GS states and the related differential gain decrease at the GS wavelength. This is the highest value ever measured on a semiconductor laser.

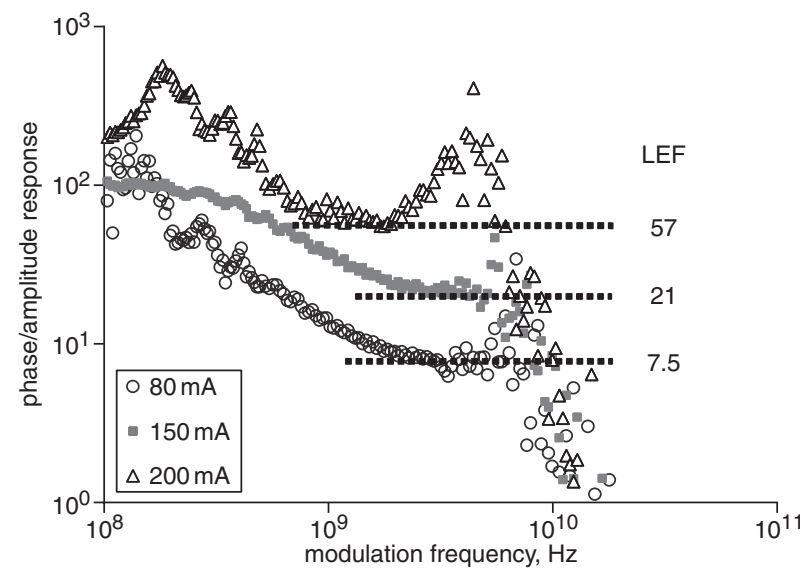

Fig. 2 Linewidth enhancement factor ( $L E F$ ) measurement on filtered GS lasing modes with interferometric method, below ES threshold

Phase/amplitude ratio measured above $3 \mathrm{GHz}$ is noisy owing to the device bandwidth

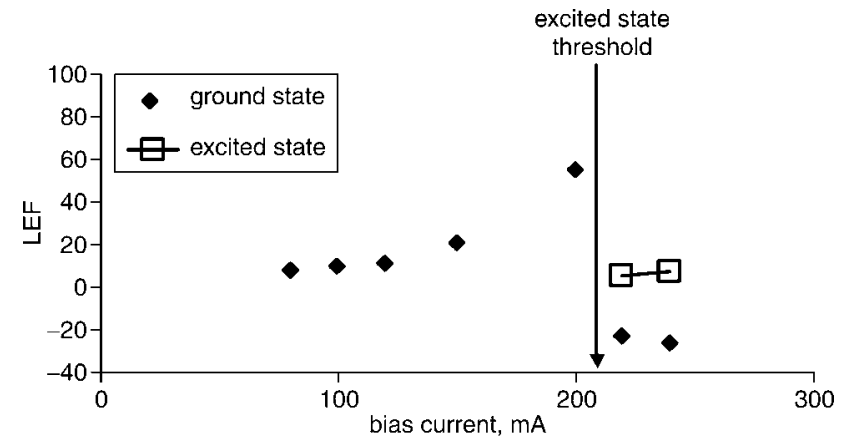

Fig. 3 GS and ES linewidth enhancement factor (LEF) against applied current

Above ES threshold, the GS differential gain, and thus the ground state LEF, becomes negative. While this effect is not well understood yet, this is the first time that a change of sign for the LEF is reported in a semiconductor Fabry-Perot laser. The excited state LEF just above the ES threshold presents values around 7, similar to the ground state LEF just above GS threshold.

Directly modulated laser FSK signal emission: The giant LEF values that have been reached suggest that direct current modulation in a properly biased QD laser will lead to frequency modulation rather than amplitude modulation. As a first application, pure frequency shift keying (FSK) signals have been encoded by simple modulation current. A $2.5 \mathrm{Gbit} / \mathrm{s} \mathrm{NRZ}$ laser modulation is realised with a pseudorandom binary sequence (PRBS) generator emitting $2^{7}-1$ 
long words. The emitted optical NRZ signal is sent to the $13 \mathrm{GHz}-$ bandwidth photodiode of an oscilloscope, without optical or electrical filtering. $2.5 \mathrm{Gbit} / \mathrm{s}$ eye diagrams (Fig. $4 a$ ) show a $6.7 \mathrm{~dB}$ extinction ratio on-off keyed (OOK) signal emitted at $60 \mathrm{~mA}$, whereas amplitude modulation vanishes at around a $180 \mathrm{~mA}$ operating point, with a 0 and 1 mark levels inversion. Noisy eye diagram at $180 \mathrm{~mA}$ is attributed to spontaneous emission increase at ES wavelength and possibly to the multimode emission of the Fabry-Perot laser: in that case the vanishing of the amplitude modulation may occur at different bias conditions for the different longitudinal modes. High resolution spectra (Fig. $4 b$ ) present the characteristic profile of a frequency modulated signal: each Fabry-Perot mode peak is split into two sub-peaks that correspond to ' 0 ' and ' 1 ' codings, respectively. The cases where ' 0 ' and ' 1 ' have the same power show us a pure frequency modulation. Fig. $4 b$ spectra reveal frequency modulation, as high as $9.7 \mathrm{GHz}$, for each GS lasing mode at $180 \mathrm{~mA}$. ' 0 ' and ' 1 ' mark amplitude contrasts of 0.5 and $-0.7 \mathrm{~dB}$, respectively at 170 and $180 \mathrm{~mA}$, demonstrating the existence of a pure frequency modulation operation point in this current range. This finally shows the possibility to generate a pure and highly contrasted FSK signal by a simple and low-consuming direct laser modulation, avoiding the usual association of a laser and a modulator.

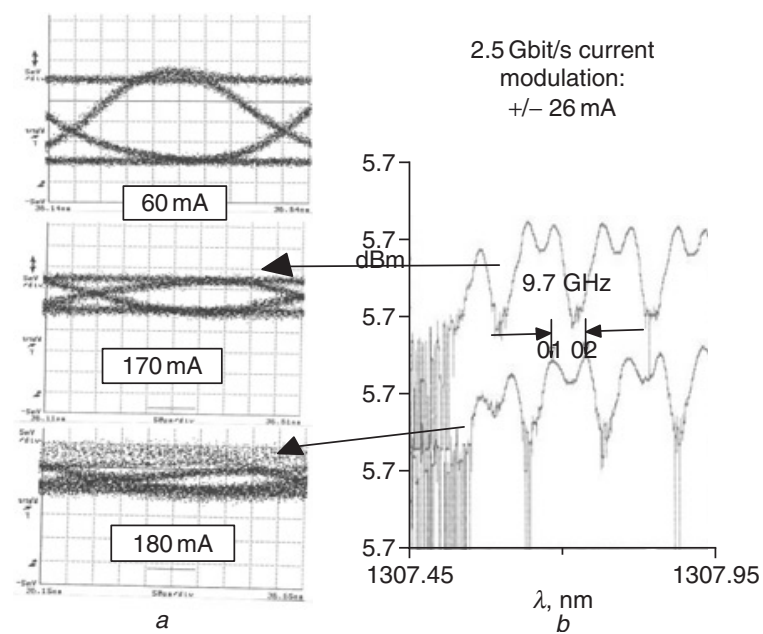

Fig. $42.5 \mathrm{Gbit} / \mathrm{s}$ unfiltered eye diagram of directly modulated $Q D$ laser for different average currents and $0.01 \mathrm{~nm}$ resolution spectra of GS modulated signal at 170 and $180 \mathrm{~mA}$

$a$ Eye diagram of directly modulated QD laser $b 0.01 \mathrm{~nm}$ resolution spectra
Conclusion: Disruptive properties including a giant effective linewidth enhancement factor, close to 60 , have been demonstrated for the first time, based on the specific electronic band structure of a quantum dot laser. As a first strategic application of these unique properties, a purely FSK signal has been shown under direct laser modulation. These results more generally demonstrate that, beside a simple improvement of performance with respect to quantum well lasers, quantum dot structures offer the perspective of new functions that could impact directly modulated lasers in addition semiconductor amplifier based devices.

(C) IEE 2005

Electronics Letters online no: 20057956

23 November 2004 doi: 10.1049/el:20057956

B. Dagens, J.-G. Provost, D. Make, O. Le Gouezigou, J. Landreau and B. Thedrez (Alcatel-Thales III-V Lab, Route de Nozay 91461 Marcoussis, France)

E-mail: beatrice.dagens@alcatel.fr

A. Markus, J.X. Chen and A. Fiore (Institute of Quantum Electronics and Photonics, EPFL, Lausanne CH-1015, Switzerland)

Present address of J.X. Chen: Bell Laboratories, Lucent Technologies Inc., 600 Mountain Ave., Murray Hill, NJ 07974, USA

Permanent address of A. Fiore: Institute of Photonics and Nanotechnology CNR-IFN, via del Cineto Romano 42, 00156 Roma, Italy

\section{References}

1 Ghosh, S., Pradhan, S., and Bhattacharya, P.: 'Dynamic characteristics of high-speed In $0.4 \mathrm{Ga} 0.6 \mathrm{As} / \mathrm{GaAs}$ self-organized quantum dot lasers at room temperature', Appl. Phys. Lett., 2002, 81, pp. 3055-3057

2 Ledentsov, N.N.: 'Long-wavelength quantum-dot lasers on GaAs substrates: from media to device concepts', IEEE J. Sel. Top. Quantum Electron., 2002, 8, (5), pp. 1015-1024

3 Markus, A., et al:: 'Simultaneous two-state lasing in quantum dot lasers', Appl. Phys. Lett., 2003, 82, pp. 1818-1820

4 Chen, J.X., et al.: 'Tuning InAs/GaAs quantum dot properties under Stranski-Krastanov growth mode for 1.3- $\mu \mathrm{m}$ applications', J. Appl. Phys., 2002, 91, pp. 6710-6716

5 Sorin, W.V., et al.: 'Frequency domain analysis of an optical FM discriminator', J. Lightwave Technol., 1992, 10, (6), pp. 787-793

6 Schimpe, R., Bowers, J.E., and Koch, T.L.: 'Characterisation of frequency response of $1.5 \mu \mathrm{m}$ InGaAsP DFB laser diode and InGaAs pin photodiode by heterodyne measurement technique', Electron. Lett., 1986, 22, (9), pp. 453-454 